\title{
ДЕЯКІ ПІДХОДИ ДО ОЦІНКИ ЦІННОСТІ ІНФОРМАЦІЙНОї ПОСЛУГИ
}

\section{SOME APPROACHES TO ESTIMATING THE VALUE OF INFORMATION SERVICES}

\author{
Кондратенко Наталя Дмитрівна \\ доцент, \\ Харківський національний університет імені В.Н. Каразіна \\ ORCID: https://orcid.org/0000-0003-2823-9905
}

Kondratenko Natalia

V.N. Karazin Kharkiv National University

\begin{abstract}
Стаття присвячена розгляду деяких підходів до оцінки цінності інформаційної послуги. Складність розгляду інформації з погляду економічної науки пов'язана з тим, що кількість інформації зростає в геометричній прогресії, що збільшує невизначеність економіки. Розглянуто використання інформації як економічного ресурсу в різних напрямках. Визначено складові інформаційних витрат, і як наслідок, інформація стає важливою складовою виробничого процесу і позбавляє переваг інші складові виробництва - природні ресурси, працю, капітал. Висвітлено кардинальні зміни структури ринку інформаційних послуг, що відбуваються внаслідок зниження попиту бізнесу та населення на техніку з поліпшеними технічними характеристиками, оскільки їі додаткові переваги незначні з точки зору більшості покупців. Розглянуто монетизація інформаційної послуги та виділено основні підходи для визначення та класифікації монетизації даних.
\end{abstract}

Ключові слова: інфрормація, інформаційна послуга, інформаційні витрати, ринок інформаційних послуг, монетизація інформаційної послуги.

Статья посвящена рассмотрению некоторых подходов к оценке ценности информационной услуги. Сложность рассмотрения информации с точки зрения экономической науки связано с тем, что количество инсрормации растет в геометрической прогрессии, что увеличивает неопределенность экономики. Рассмотрено использование информации как экономического ресурса в разных направлениях. Определены составляющие инорормационных затрат, и как следствие, инорормация становится важной составляющей производственного процесса и лишает преимуществ другие составляющие производства - природные ресурсы, труд, капитал. Освещены кардинальные изменения структуры рынка информационных услуг, происходящие вследствие снижения спроса бизнеса и населения на технику с улучшенными техническими характеристиками, поскольку ее дополнительные преимущества незначительны с точки зрения большинства покупателей. Рассмотрены монетизация информационной услуги и выделены основные подходы к определению и классификации монетизации данных.

Ключевые слова: информация, информационная услуга, информационные затраты, рынок информационных услуг, монетизация информационной услуги.

The rapid process of the scientific and technological revolution and the digitalization of the economics in a special way actualize some concepts that a few years ago seemed mundane and trivial. And such concepts can rightly include information. The difficulty of considering information from the point of view of economics is due to the fact that the amount of information increases exponentially, which increases the uncertainty of the economics. The purpose of this article is to consider some approaches to assessing the value of the information services. The keen interest in the information in our time is primarily associated with formation of the information society, when information began to affect all spheres of economic life. In the information society, information itself enters the turnover, forming part of the value of the goods. The use of information as an economic resource is considered in different directions. Among the main ones were: commercialization of information in goods, services, technologies; influence on subjective perceptions and expectations of economic entities. Modern information products are mixed information goods that combine explicit and implicit information. The components of the information costs are identified, and as a result, information becomes an important component of the production process and deprives other components of production - natural resources, labor, capital. Radical changes in the structure of the information services market are highlighted - the share of information goods is gradually decreasing with a faster growth of the share of information 
services due to declining business and population demand for equipment with improved technical characteristics, as its additional benefits are insignificant from most buyers. The monetization of the information services is considered - making a profit from information through the introduction of paid services, advertising, links, etc. The main approaches to the definition and classification of data monetization are identified: direct monetization, which consists of the sale or trade of data; indirect monetization, which uses data analytics to get an idea of the causal relationships and patterns of complex processes for better decision making.

Keywords: information, information service, information costs, information services market, monetization of information service.

Постановка проблеми. Інтенсивний процес науково-технічної революції й цисровізація економіки особливим чином актуалізують деякі поняття, які ще декілька років тому здавалися повсякденними й тривіальними. I до таких понять 3 повним правом можна віднести інформацію. Складність розгляду інфрормації 3 погляду економічної науки пов'язана 3 тим, що кількість інорормації зростає в геометричній прогресії, що збільшує невизначеність економіки.

Поняття інформації не є для економічної науки зовсім новим. Перші згадування про інфрормацію ми можемо зустріти у класиків А. Сміта й Д. Рикардо [1]. Р. Коуз ввів у науковий оборот поняття трансакційні витрати, існування яких пов'язував зі збором необхідної інорормації перед укладанням угоди. «Трансакційні витрати - це різниця між даною ціною пропозиції й можливості більш низької ціни, яка сплачується покупцем як альтернатива більше високим витратам пошуку, інформації, очікування й виробництва» [2]. Але в даних дослідженнях не розглядається сутність інорормації, що пов'язана з тим, що роль витрат на ії одержання була незначна, самі витрати носили епізодичний характер. Виграш від одержання інформації, звичайно, існував, але не був обов'язковим для одержання прибутку. Можна сказати, що в цей період інфрормаційний ресурс не мав ще чіткої товарної форми.

У процесі розвитку цивілізації поняття та визначення інфрормації змінювалося. 3'явилася потреба в науковому підході до поняття інформація й визначенню їі властивостей. Інформація й здатність її раціонального використання починають розглядатися не як прикладне поняття, а як самостійний напрямок наукової й професійної діяльності.

Аналіз останніх досліджень і публікацій. Природу інсрормаційних ресурсів та інформаційного продукту в економіці досліджували Д.Г. Плахотна, А.І. Московський, А.А. Аузан, Р.Т. Зяблюк, Р.П. Малахінова, Р.І. Цвилев та інші. Особливо слід відзначити праці С. Малахова і Р. Капелюшнікова [3], в яких проблеми інфрормації розглядалися у зв'язку з трансакційними витратами, а також роботи Е. Маймінаса, в яких він досліджував соціально-економічні аспекти інформації [4].

Пильний інтерес до інфрормації в наш час пов'язаний насамперед із формуванням інформаційного суспільства, коли інформація стала впливати на всі сорери економічного життя. В інфрормаційному суспільстві сама інформація надходить в товарообіг, складаючи частину вартості товару.

Формулювання цілей статті. Метою даного дослідження є з'ясування особливостей ринку інфрормаційних послуг та розгляд деяких підходів щодо оцінки цінності інсрормаційної послуги.

Виклад основного матеріалу дослідження. В умовах експоненціального збільшення інформації економічні агенти в процесі виробництва, розподілу, обміну та споживання матеріальних та духовних благ керується розмитими критеріями есрективності, оскільки володіють зазвичай обмеженою (асиметричною) інфрормацією. В свою чергу, це призводить до збільшення невизначеності ринку та загострення економічної та політичної турбулентності (в тому числі, при можливій маніпуляції з інфрормацією).

Із розвитком ринків зростає кількість індрормаційних зв'язків. Спотворення чи асиметрія інформації впливає на успішність економічної діяльності як на макро- так і на мікрорівні. Тому в будь-якій економічній діяльності важливо мати достовірну інорормацію.

Споживчі властивості будь-якої інфрормації визначаються процесами відбору, переробки та надання у відповідних видах і орормах відомостей, при використанні яких споживач із урахуванням його економічних, соціальних та інших можливостей і особливостей зможе з максимальним успіхом досягати поставлених ним стратегічних цілей і вирішити тактичні завдання. Ринок інформаційних послуг містить у собі не тільки ринок інфрормації, але й ринки супутніх товарів і послуг.

На цей час однією з найбільш актуальних $є$ проблема сильного інформаційного тиску на 
людей, що посилюється з прискоренням розвитку інфоормаційних систем. Інформація як економічний ресурс використовується в різних напрямках. Серед основних слід виділити наступні:

- комерціалізація інфрормації в товарах, послугах, технологіях (створення наукомісткої продукції, інтелектуальних товарів, інфрормаційних послуг, розробка нових технологій виробництва й управління тощо);

- вплив на суб'єктивні сприйняття й очікування економічних суб'єктів. Як приклади можна привести створення інфрормаційного образу продукту, компанії (репутація), фрормування потреб або впливу на них за допомогою інформації.

Отже, інсрормація в економіці проявляється в безлічі аспектів. Це, насамперед, перетворення виробництва інсрормації в галузь економічної діяльності. Крім того, інфрормація перетворюється на об'єкт купівліпродажу, тобто виступає як товар, стає фрактором виробництва, одним із фундаментальних ресурсів будь-якої економічної системи, елементом ринкового механізму, що поряд із ціною та корисністю впливає на визначення оптимального й рівноважного станів економічної системи й стає одним із найбільш важливих фракторів конкурентної боротьби.

Сучасні інфрормаційні продукти представляють собою змішані інформаційні блага, які поєднують явну й неявну інорормацію. 3 одного боку, в основі сучасної інформаційної послуги лежить певний інсооммаційний продукт (ПЗ або навчальний курс), проте, 3 іншого боку, для оволодіння цією інфоормаційною послугою індивідуальний споживач має володіти певним набором вмінь та навичок для користування послугою. В результаті цього, споживачі для максимізації корисності від споживання інформаційних послуг мають докласти певні зусилля для фрормування в себе вмінь, навичок і культури споживання, а підприємці збільшити витрати на створення неявної інорормації, яка необхідна для вбудовування універсального знання в бізнеспроцеси (наприклад, онлайн-торгівля або онлайн-освіта).

Такими чином, необхідно визначити складові інфоормаційних витрат, які включають в себе:

- витрати підприємців на створення інорормаційної послуги та витрати на інфрормаційне забезпечення інфрормаційної послуги;

- витрати підприємців на збір інфрормації про ринок інфрормаційних послуг, реальних та уявних відмінностях інсрормаційної послуги на цьому ринку, їі реальну якість, супутні послуги та товари тощо;

- витрати споживачів на придбання самої інорормаційної послуги;

- витрати споживачів на навчання та набуття досвіду (змішана інформаційна послуга, наприклад, навчальний курс, або власна неявна інфрормація);

- витрати на послуги консультантів (оплата праці тьютора при он-лайн навчанні чи консалтингових агентств щодо аналізу ринку).

Як наслідок, інфрормація стає важливою складовою виробничого процесу і позбавляє переваг інші складові виробництва - природні ресурси, працю, капітал. Можна сказати, що інорормація служить мірою впорядкованості та стабільності економічної системи. Підприємства, які ефрективно перетворюють інфрормацію, стають більш конкурентоспроможними ніж ті, які цього не роблять i, займаючись «традиційними» формами економічної діяльності, частіше програють у конкурентній боротьбі. Перетворення інорормації стає вирішальною складовою як у постачанні, так і збуті. Ії̈ можна розглядати як єдину субстанцію, що поєднує предмети, засоби та продукти праці. Так виробники прагнуть заздалегідь досліджувати кон'юнктуру ринку, готові заплатити великі гроші за інфрормацію про продукцію конкурента. Саме цим зайняті всі фрірми у галузі бенчмаркінгу. Крім того, все більш значні кошти витрачаються на рекламу, яка теж $\epsilon$ інформацією та складовою частиною ціни товару.

Аналіз ринку інфрормаційних послуг свідчить про кардинальні зміни його структури поступово зменшується частка інорормаційних товарів при випереджаючому зростанні питомої ваги інформаційних послуг. Такі трансорормації відбуваються внаслідок зниження попиту бізнесу та населення на техніку з поліпшеними технічними характеристиками, оскільки її додаткові переваги незначні 3 точки зору більшості покупців (наприклад, новий Apple iPhone 12 кардинально не відрізняється від попередньої моделі). Для бізнесу частка інсрормаційних послуг збільшується через зростаючу складність нових інфрормаційних систем, в результаті чого збільшуються витрати фрірми на установку та обслуговування обладнання.

Структурні зміни ринку інфрормаційних послуг свідчать про його перехід до більш зрілої стадії свого розвитку. Вважаємо можливим зауважити щодо структурних змін ринку 
інфрормаційних послуг за критерієм їх призначення, що виявляється у зростанні питомої ваги інформаційних послуг призначених для проміжного споживання у їх внутрішньому споживанні і через зростання кінцевого споживання інфрормаційних послуг порівняно 3 накопиченням, що виявлено через збільшення частки кінцевого споживання у їх кінцевому внутрішньому використанні.

Сьогодні найбільші за капіталізацією компанії світу отримують прибуток саме за рахунок продажу інфрормаційних послуг. Apple займається виробництвом інфрормаційних продуктів з високою часткою інфрормаційних послуг, Google займає 90\% ринку пошукових послуг, Microsoft надає інорормаційні продукти, Amazon (інсрормаційні послуги), Facebook (інфрормаційні послуги).

Amazon не зосереджується на короткострокових прибутках, а розробляє стратегії збільшення частки на ринку. На сьогодні він вже займає близько 39\%, в результаті цього, не зважаючи на низьку операційну рентабельність (продаж товарів в роздріб збиткова), компенсує операційний дефріцит завдяки розвитку хмарної служби Amazon Web Services (AWS), яка генерує грошовий потік за рахунок надання різноманітних інфрормаційних послуг для підприємців. В результаті цього Amazon Web Services в 2019 р. принесла прибуток у 9,2 мільярда доларів, що склало більше половини всього прибутку Amazon [6]. Результатом застосування нової прогресивної бізнесмоделі, ринкова капіталізація Amazon зросла на $2830 \%$ за останнє десятиліття.

Інформаційні послуги та реклама збільшують доходи всіх компаній Big Tech. Дохід Alphabet від реклами в мережі Google виріс на 20 млрд дол., а хмарна служба Google Cloud, яка надає інфрормаційні послуги, принесла 8,9 мільярда доларів прибутку. Для Microsoft зростання хмарних обчислень та інформаційних послуг збільшило доходи майже в усіх сегментах. А більш широке розповсюдження інформаційних послуг та інтеграція реклами стали великим стимулом для Facebook. Багато в чому завдяки постійному зростанню середнього доходу на одного користувача, Facebook отримав додаткові 20 млрд доларів доходу [5].

В умовах цисрровізації економіки, виникають нові можливості для бізнесу, оскільки 3'являється необхідність оцінити вартість та цінність інорормації. За даними, Gartner, серед десяти основних проблем представників великого бізнесу, проблема, яка пов'язана із вилученням користі з інсрормаційних даних та проблеми, які пов'язані зі значущістю інорормації [8].

Таким чином, важливим фрактором розвитку ринку інформаційних послуг стає проблема монетизації інфрормації. Монетизація інформаційної послуги - отримання прибутку 3 інфрормації за рахунок введення платних сервісів, розміщення реклами, посилань тощо. Серед стандартних фрорм монетизації сьогодні можна виділити наступні:

- монетизація інсрормації, при якій за неї платять рекламодавці (медіа-реклама, контекстна реклама, замовні статті);

- монетизація, за яку сплачують безпосередні споживачі інформації (різні клієнтські сервіси, розміщення приватних оголошень; розділи 3 консультаціями фрахівців (юристів або економістів); калькулятори валют чи рідкісний контент, який надається на платній основі (Paywall). Найбільш популярною $€$ модель, в якій безкоштовна інсрормація поєднується із спеціалізованою платною, яка має вищу додану вартість (раніше надається, більша за величиною, $є$ можливість отримати додаткові інсрормаційні послуги тощо). Наприклад, газета The Wall Street Journal надає безкоштовний доступ до основної інфрормації, проте, за вузькопросрільну інфрормацію споживач має заплатити;

- монетизація, за яку сплачують треті особи - різні спонсорські проекти, партнерські програми, благодійність та краундфрандінг.

Доходи світових технологічних гігантів

Таблиця 1

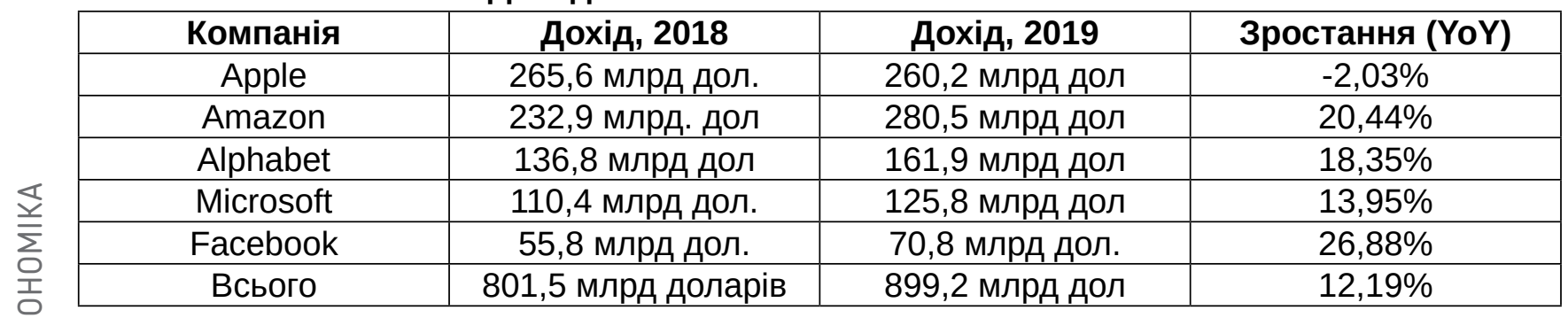


Концепція партнерських програм реалізується шляхом інтеграції на сайт різних програм партнерів та отримання певного відсотка (або платежу) від продажу їх товарів або послуг. Британське видання Guardian має успішний досвід партнерської угоди із інтернет-магазином Amazon. Достатньо новим $€$ інститут краундфрандінгу, за якого фрізичні та юридичні особи самостійно сплачують виробництво певного інорормаційного продукту чи послуги.

Таким чином, вважаємо можливим виділити такі основні підходи для визначення та класисрікації монетизації даних:

1. пряма монетизація, яка складається з продажу або торгівлі даними третім особам. Комерційні підприємства можуть використовувати цей метод для негайного отримання доходу від продажу інорормації. Перш ніж запровадити пряму монетизацію слід визначити:

- вартість інформації, яку буде встановлено разово для кожного споживача або через встановлення підписки;

- розділити інфрормацію за різними класифрікаційними критеріями для визначення вартості кожного блоку для максимізації прибутку;

- розробити та надати додаткові послуги розробка інтерфейсів, мобільних додатків тощо.

2. непряма монетизація, яка використовує аналітику даних для отримання уявлення про причинно-наслідкові зв'язки та закономірності складних процесів для прийняття кращих рішень. Компаніям необхідно розраховувати та використовувати результати аналітичних проектів для розробки нових продуктів, зниження ризиків та максимізації прибутку від монетизації.

Аналітика даних виконує завдання якісного змістовного перетворення інформації. Аналітика даних тісно пов'язана із Big Data, які представляють собою великі набори структурованої та неструктурованої інсрормації, які неможливо проаналізувати за допомогою традиційних методів аналізу. Яскрава ілюстрація великих даних - це безперервність надходження інфрормації з пристроїв аудіо- і відеореєстрації, потоки текстових та відеоповідомлень 3 соцмереж, координати геолокації абонентів мобільного зв'язку.

Основною характеристикою великих даних $\epsilon$ експоненціальне прискорення їх створення та нагромадження, а також ступінь їх структурованості і варіантів представлення. Таким чином, основними характеристиками Big Data $€$ :

- обсяг, який забезпечує кількість даних, генерується щосекунди та може складатися із терабайтів, петабайтів та ексабайтів інформації;
- швидкість, 3 якою генеруються дані; швидкість залежить від розвитку електронних каналів зв'язку та потужності засобів обчислювальної техніки (3G, 5G або 6G);

- різноманітність - генеруються різнорідні типи даних (текст, картинка, музика тощо);

- цінність - визначення максимальної кількості релевантної інсрормації для максимізації корисності споживачів інорормації;

- точність даних - аналіз даних 3 точки зору правдивості, фрейковості, застарілості та структурованості.

Щодня Інтернет заповнюється величезною кількістю інсрормації, що розвиває концепцію великих даних. Відбувається оцифрування всієї наявної інфоормації, в першу чергу інфрормації в соціальних медіа, музиці, відео, онлайнкнигах тощо. Оцифрруванню піддається не тільки все, що відбувається в Інтернет (пошук текстів, електронні листи, відвідування всіх сайтів, всі пошукові запити, введення бухгалтерських проводок, продаж продукції клієнтам, транзакції клієнтів тощо), але й аналізуються поведінкові аспекти споживачів - місцезнаходження користувача, його бажання, потреби, норми поведінки, стан здоров'я (за допомогою орітнестрекерів) тощо. Така інфрормація збирається та переводиться в анонімну форму для перетворення на інформаційну послугу, яка продається великим торгівельнім мережам, фрінансовим та страховим компаніям.

Завдяки подібним інформаційним послугам та сучасній аналітиці даних великі компанії отримують доступ до інсоормації про потреби, вподобання і інші особливості поведінки споживачів, які раніше просто не можливо було отримати. Наприклад, за допомогою аналітики даних зменшується асиметричність інформації на ринку страхових послуг, оскілки у страхових компаній з'являється можливість отримати реальні дані про здоров'я страхувальника, стан його нерухомості, стиль водіння автомобілем. Наприклад, страхові компанії встановлюють в автомобілі спеціальні електронні пристрої, які реєструють всі дані про стиль водіння, характеристику змін тиску та серцебиття страхувальника. Scyllogis Consulting пропонує страховим компаніям інфрормаційні послуги щодо споживачів страхових послуг для покращення їх роботи із клієнтами [7]. В результаті страхові компанії адаптують та персоналізують страхові продукти відповідно до конкретних потреб клієнтів, що зменшує асиметричність інорормації та трансакційні витрати.

Таким чином, аналітика даних дозволяє виявляти приховані закономірності та при- 


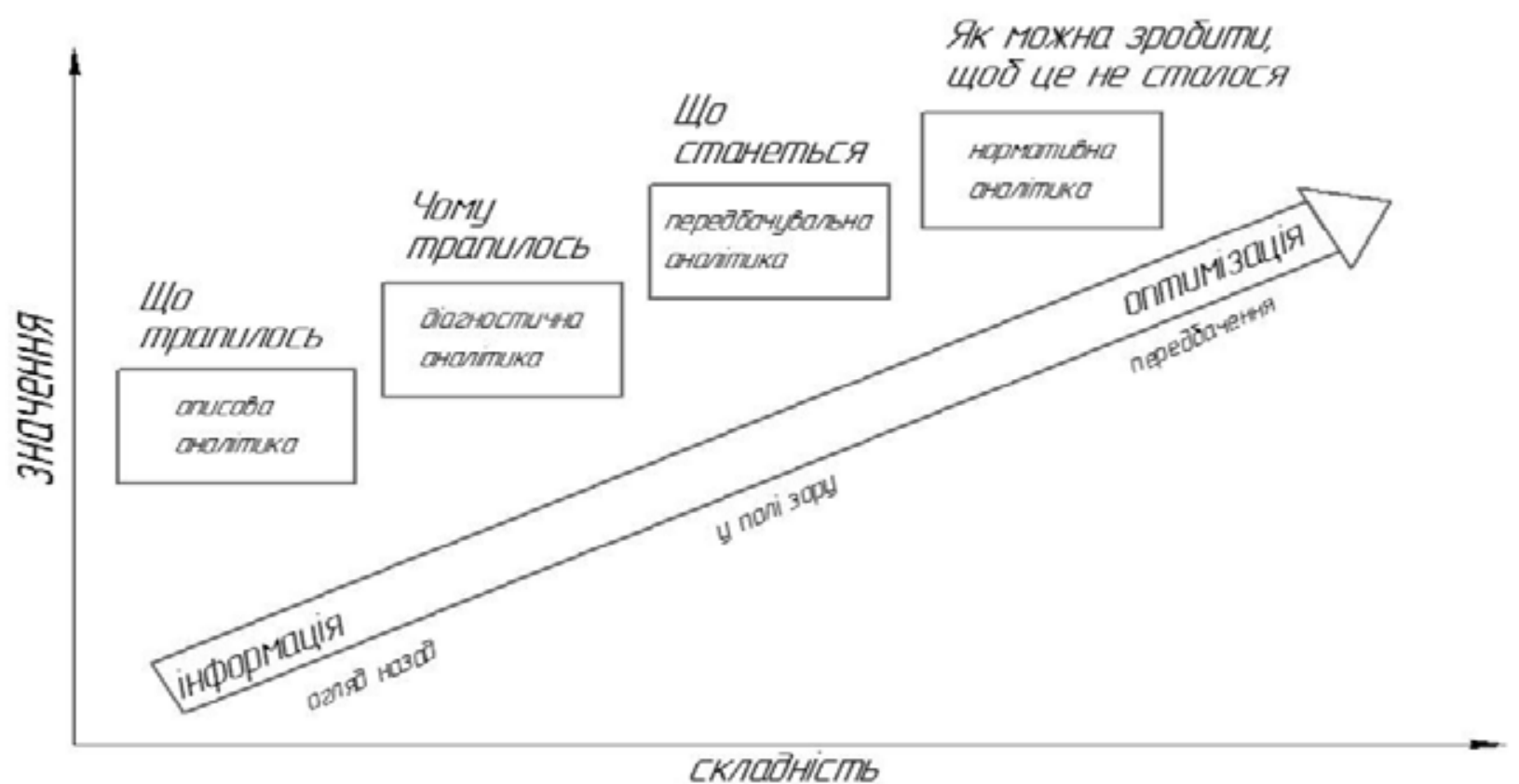

Рис. 1. Структурні етапи аналітики даних [8]

чинно-наслідкові зв'язки, що були недоступними для обмеженого людського сприйняття. Це дає безпрецедентні можливості оптимізації багатьох сорер економіки, серед яких державне управління, фрінанси, медицина, освіта, телекомунікаційна галузь, транспорт тощо. Аналітика даних має відповіти на наступні питання (рис. 1).

Вважаємо, що аналітику даних можна розділити на наступні етапи:

- описова аналітика (що сталося?) - на основі даних (різні інструменти звітування бухгалтерські звіти та інфрормаційні панелі) показ того, що насправді відбувається;

- діагностична аналітика (чому це сталося?) - аналіз наявної інфрормації та на її основі визначення не тільки того, що сталося, але, що найголовніше, чому це сталося;

- прогностична аналітика (що може статися?) - опис різноманітних можливих сценаріїв розвитку подій;

- аналіз приписів (що нам робити?) - розробка пропозицій щодо того, що слід робити для збільшення ефективності фрункціонування суб'єкта господарювання.

Аналітика даних та Big Data $€$ лише однією 3 особливостей цифррової трансформації економічної системи, оскільки представляють собою новий інститут, в якому, з одного боку, знайшли втілення інсоормаційні тренди останніх десятиріч; з іншого - він сам здатен впливати й реально трансформувати існуючі виробничі відносини та моделі поведінки суб'єктів гос- подарювання, в результаті чого відбувається трансформація всієї економічної системи.

Висновки. Отже, масштаби оцінки цінності інфрормації для будь-якої організації практично нескінченні, що потребує підвищеної уваги науковців та практиків до проблеми оцінки цінності інформаційної послуги в умовах цифррової транссоормації економіки. Вважаємо можливим виділити такі основні підходи для визначення та класифрікації монетизації даних: пряма монетизація, яка складається з продажу або торгівлі даними третім особам; непряма монетизація, яка використовує аналітику даних для отримання уявлення про причиннонаслідкові зв'язки та закономірності складних процесів для прийняття оптимальних рішень.

Аналіз ринку інформаційних послуг свідчить про суттєві зміни його структури - досить поступово зменшується частка інфрормаційних товарів при інтенсивному зростанні питомої ваги інорормаційних послуг. Структурні зміни ринку інсрормаційних послуг свідчать про його перехід до більш зрілої стадії свого розвитку. Вважаємо можливим зауважити щодо структурних змін ринку інформаційних послуг за критерієм їх призначення, що виявляється у зростанні питомої ваги інфоормаційних послуг призначених для проміжного споживання у їх внутрішньому споживанні і через зростання кінцевого споживання інфрормаційних послуг порівняно з накопиченням, що виявлено через збільшення частки кінцевого споживання у їх кінцевому внутрішньому використанні. 


\section{СПИСОК ВИКОРИСТАНИХ ДЖЕРЕЛ:}

1. В. Петти, А. Сміт, Д. Рикардо. Анталогия экономической классики. Москва : Эконов, Ключ, 1993. 478 с.

2. Коуз Р. Фирма, рынок и право / пер. с англ. Б. Пинскера. Москва : Дело ЛТД, 2007. 224 с.

3. Капелюшников Р. Экономические очерки: методология, институты, человеческий капитал. Москва : Изд. дом Высшей школы экономики, 2016. 574 с.

4. Майминас Е. Информационное общество и парадигма экономической теории. Вопросы экономики. 1997. № 11. C. 90-95.

5. How Big Tech Makes Their Billions. July 6, 2020. URL: https://www.visualcapitalist.com/how-big-tech-makestheir-billions-2020/ (accessed 25 October 2020).

6. Visualizing the Size of Amazon, the World's Most Valuable Retailer. URL: https://www.visualcapitalist.com/ amazon-worlds-most-valuable-retailer/ (accessed 29 October 2020).

7. Scyllogis Consulting. Insurance digital transformation experts. URL: https://www.scyllogis.com/who-we-are/ (accessed 29 October 2020).

8. Gartner. URL: https://www.gartner.com/en (accessed 29 October 2020).

\section{REFERENCES:}

1. Petti V., Smit A., \& Rikardo D. (1993). Antalogiya ekonomicheskoy klassiki [An anthology of economic classics]. Moscow: Ekonov: Klyuch. (in Russian)

2. Kouz R. (2007). Firma, rynok i pravo [Firm, market and law] / Pinsker B. (perevod s angliyskogo). Moscow: Delo LTD. (in Russian)

3. Kapeljushnikov R. (2016). Jekonomicheskie ocherki: metodologija, instituty, chelovecheskij capital [Economic essays: methodology, institutions, human capital]. Moscow: Izdatel'skij dom Vysshej shkoly jekonomiki. (in Russian)

4. Majminas E. (1997). Informacionnoe obshhestvo i paradigma jekonomicheskoj teorii [Information society and the paradigm of economic theory]. Voprosy jekonomiki - Economic issues, 11, 90-95.

5. How big tech makes their billions (2020). Retrieved from: https://www.visualcapitalist.com/how-big-techmakes-their-billions

6. Visualizing the size of Amazon, the world's most valuable retailer (2020). Retrieved from: https://www.visualcapitalist.com/amazon-worlds-most-valuable-retailer

7. Scyllogis consulting. insurance digital transformation experts (2020). Retrieved from: https://www.scyllogis.com/ who-we-are

8. Gartner (2020). Retrieved from: https://www.gartner.com/en 